\title{
Shallow firn cores from Neumayer, Ekströmisen, Antarctica: a comparison of accumulation rates and stable-isotope ratios
}

\author{
Elisabeth SCHLOSSER, ${ }^{1}$ Hans OERTER ${ }^{2}$ \\ ${ }^{1}$ Institute of Meteorology and Geophysics, University of Innsbruck, Innrain 52, A-6020 Innsbruck, Austria \\ E-mail: elisabeth.schlosser@uibk.ac.at \\ ${ }^{2}$ Alfred Wegener Institute for Polar and Marine Research, Columbusstrasse, D-27268 Bremerhaven, Germany
}

\begin{abstract}
Since 1979/80, glaciological studies have been carried out at Ekströmisen, Antarctica, including accumulation-stake measurements, snow-pit and shallow-firn-core studies. Snow stratigraphy, chemical properties and stable-isotope ratios $\left(\delta^{18} \mathrm{O}\right)$ were investigated. This study focuses on three cores taken between 1982 and 1998. The 1998 core was dated using dielectric profiling, $\delta^{18} \mathrm{O}$ profiles and stake measurements. Accumulation rates show high interannual and spatial variability due to the extreme wind influence. No significant trend was found for the last 50 years; during the first half of the 20th century, accumulation decreased. The high spatial and interannual variability, however, means that trends must be interpreted with care. In spite of the highly irregular accumulation distribution, stable-isotope ratios show little spatial variability. The mean annual $\delta^{18} \mathrm{O}$ values of cores B04 and FB0198 agree fairly well for the time period 1955-82 covered by both cores. $\delta^{18} \mathrm{O}$ values have increased during most of the 20th century; since the late 1980 s a decrease is observed. This change is not related to air temperature, since mean annual air temperatures at Neumayer show no significant trend over the last two decades.
\end{abstract}

\section{INTRODUGTION}

In the ongoing discussion of climatic change, the mass balance of Antarctica has received increasing attention during recent decades, since its reaction to global warming will strongly influence sea-level change. Many different compilations of Antarctic mass balance, using models and measurements, have been published (Giovinetto and Bentley, 1985; Bentley and Giovinetto, 1991; Van Lipzig, 1999; Giovinetto and Zwally, 2000). However, the uncertainties are still relatively large due to the size of the continent and a lack of measurements in some parts of it. Additionally, the response time of the enormous ice sheet to a change in climate is very large. Thus it is difficult to relate changes in the extent or height of the ice sheet to climatic change on time-scales of decades or centuries. Accumulation rates were found to be sensitive to changes in air temperature (Giovinetto and others, 1990) and thus are more suitable for studying possible changes in climate. A decrease in air temperature usually leads to a decrease in accumulation rates since colder air can hold less moisture than warmer air, so precipitation amounts tend to decrease, even if the number of precipitation events does not change. There are, however, other possible reasons for accumulation-rate changes, such as changes in the mean atmospheric circulation that alter storm tracks, frequency of storms or origin of precipitation. In different parts of Antarctica, opposite accumulation-rate trends were observed (Morgan and others, 1991; Peel, 1992; Isaksson and others, 1996; Oerter and others, 2000; Graf and others, 2002).

In this study, we present accumulation and stable-isotope data from three firn cores taken close to the German Antarctic base "Neumayer", on Ekströmisen, on the coast of Dronning Maud Land. The first mass-balance studies in western
Dronning Maud Land were carried out by members of the Norwegian-British-Swedish Antarctic Expedition in 194952 (Swithinbank, 1957; Schytt, 1958a, b). From their wintering base "Maudheim" on Quarisen the members of this expedition undertook long sledge journeys during which they also crossed Ekströmisen.

Glaciological studies have been carried out on Ekströmisen since the pre-site survey for the first German base "Georg von Neumayer" $\left(70^{\circ} 37^{\prime} \mathrm{S}, 8^{\circ} 22^{\prime} \mathrm{W}\right)$ in $1979 / 80$ (Reinwarth and others, 1982, 1985). These included accumulation-stake measurements, snow-pit and shallow firn-core studies, at first in order to obtain information about accumulation rates at the construction site of the base, and later for isotope and chemical investigations. In this study, three cores taken between 1982 and 1998 are presented. Different dating methods, accumulation rates and stable-isotope ratios of these cores are compared and discussed.

\section{DATA}

A stake array was installed $700 \mathrm{~m}$ south of the Georg von Neumayer station $(\mathrm{GvN})$ in March 1981. Since then, the number of stakes and the site of the array have changed only slightly. When a new base, "Neumayer" $\left(70^{\circ} 39^{\prime} \mathrm{S}, 8^{\circ} 15^{\prime} \mathrm{W}\right)$, was constructed in 1992, a new stake array was set up. The old and the new array were run simultaneously for 2 years. During this time, the new array showed the same accumulation events, but higher accumulation amounts than the old one. However, comparison with a firn core taken at the construction site in 1989, before the new base was built, shows a good agreement of accumulation rates at GvN and Neumayer, respectively. Thus we assume that the higher values observed during the first 2 years after the construc- 


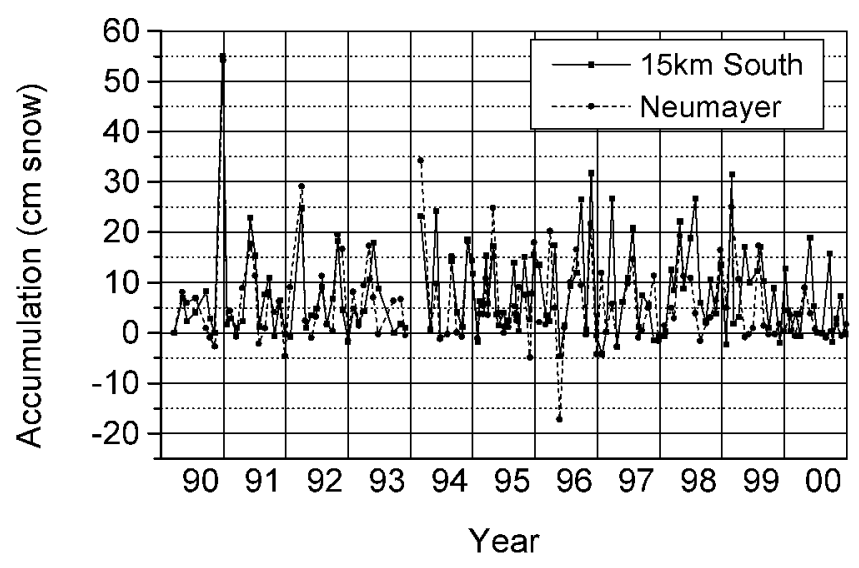

Fig. 1. Monthly accumulation measured at stake arrays Neumayer $/ G v \mathcal{N}$ and " $15 \mathrm{~km}$ South", respectively. Values are given in cm snow to avoid errors in calculation of water equivalent due to uncertainties in density.

tion are due to the influence of the station building, which after 3 years should have disappeared, since the station was close to the level of the surrounding surface by that time. Today the array consists of 25 metal stakes of $2 \mathrm{~m}$ length and is situated about $1 \mathrm{~km}$ southeast of the station. Stakes are arranged in a quadrat with a distance of about $5 \mathrm{~m}$ between stakes. Accumulation was measured on a weekly basis, except for 1983, when only monthly readings were carried out. Although some melting is observed at the surface in summer, the stakes remained frozen to the surrounding snow at lower levels and did not melt in. The snow surface was usually fairly rough, with sastrugi varying in size, but the mean of the snow-height changes should give a reasonable value for the accumulation. Settling of the snow cover is very small, and in the weekly measurements negligible compared to erosion due to wind influence (Schlosser, 1999).

Another stake array was set up in 1987, about $15 \mathrm{~km}$ south of GvN (now $10 \mathrm{~km}$ south of Neumayer), at the traverse route to the Ritscherflya south of Ekströmisen. It is similar to that at Neumayer, but consists of only 16 stakes, which are read once per month. Figure 1 shows monthly accumulation rates measured at stake arrays Neumayer and " $15 \mathrm{~km}$ South". The correlation of these two time series is fairly good $(r=0.71)$. Accumulation at " $15 \mathrm{~km}$ South" is higher than at Neumayer in many cases, which might be due to less erosion. More details about the stake measurements can be found in Schlosser (1999) and Schlosser and others (1999).

Snow density is required in order to calculate accumulation (mm w.e.) from the snow-height changes. Unfortunately, no density measurements of freshly fallen snow are available. Densities observed in the uppermost $10-20 \mathrm{~cm}$ of snow pits are $300-460 \mathrm{~kg} \mathrm{~m}^{-3}$. Usually the highest values are found in pits dug in summer after a longer clear-weather period when the snow has had time to settle. In winter and immediately after a snowfall/drift event the density is lower. Usually, large amounts of accumulation mean less windpacked snow, as previously observed at Maudheim (Swithinbank, 1957). Therefore we used a mean density of $360 \mathrm{~kg} \mathrm{~m}^{-3}$ to calculate accumulation rates.

Snow pits which usually covered $1-2$ years accumulation were dug, and shallow firn cores were taken at irregular time intervals, mostly during summer. The depth of the firn cores is $10-52 \mathrm{~m}$. Snow stratigraphy, chemical properties and stable-isotope ratios $\left(\delta^{18} \mathrm{O}\right)$, and in some cases tritium

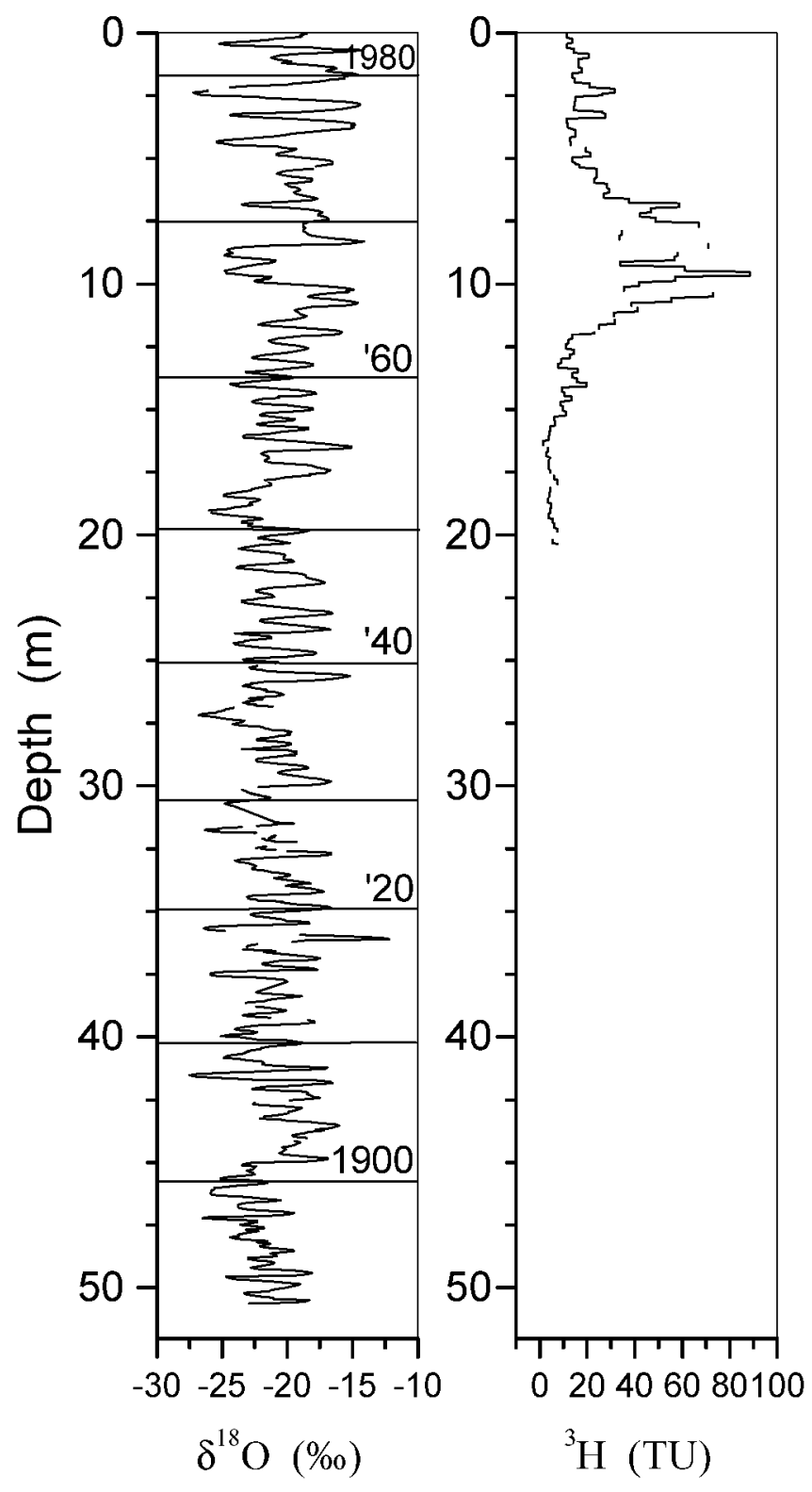

Fig. 2. $\delta^{18} \mathrm{O}$ and ${ }^{3} \mathrm{H}$ profiles of the $52 \mathrm{~m}$ core $\mathrm{B} 04$ taken in 1982 (Schlosser and others, 1999).

contents, were investigated. The cores were usually dated using the seasonal variations of stable isotopes. Detailed information about these data can be found in Schlosser and others (1999). Additionally, samples of freshly fallen surface snow were taken after major snowfall events. These samples were also analyzed for isotope studies.

This study focuses on three cores:

B04, drilled at GvN in 1982 with a length of $52 \mathrm{~m}$;

FB0189, drilled in December 1989 at the planned construction site of Neumayer station to $10 \mathrm{~m}$ depth (Schlosser and others, 1999);

FB0198, drilled in December 1997 adjacent to stake array " $15 \mathrm{~km}$ South" with a length of $27.8 \mathrm{~m}$.

FB0198 was also dated using dielectric-profiling (DEP) measurements.

Figure 2 shows the $\delta^{18} \mathrm{O}$ and ${ }^{3} \mathrm{H}$ profiles of $\mathrm{B} 04$. The dating of this core was cross-checked using the tritium profile (cf. Graf and others, 1999; Oerter and others, 1999), resulting in a mean accumulation rate of $360 \mathrm{~kg} \mathrm{~m}^{-2} \mathrm{a}^{-1}$ for the period 1952-82. This agrees well with the dating using the stable- 


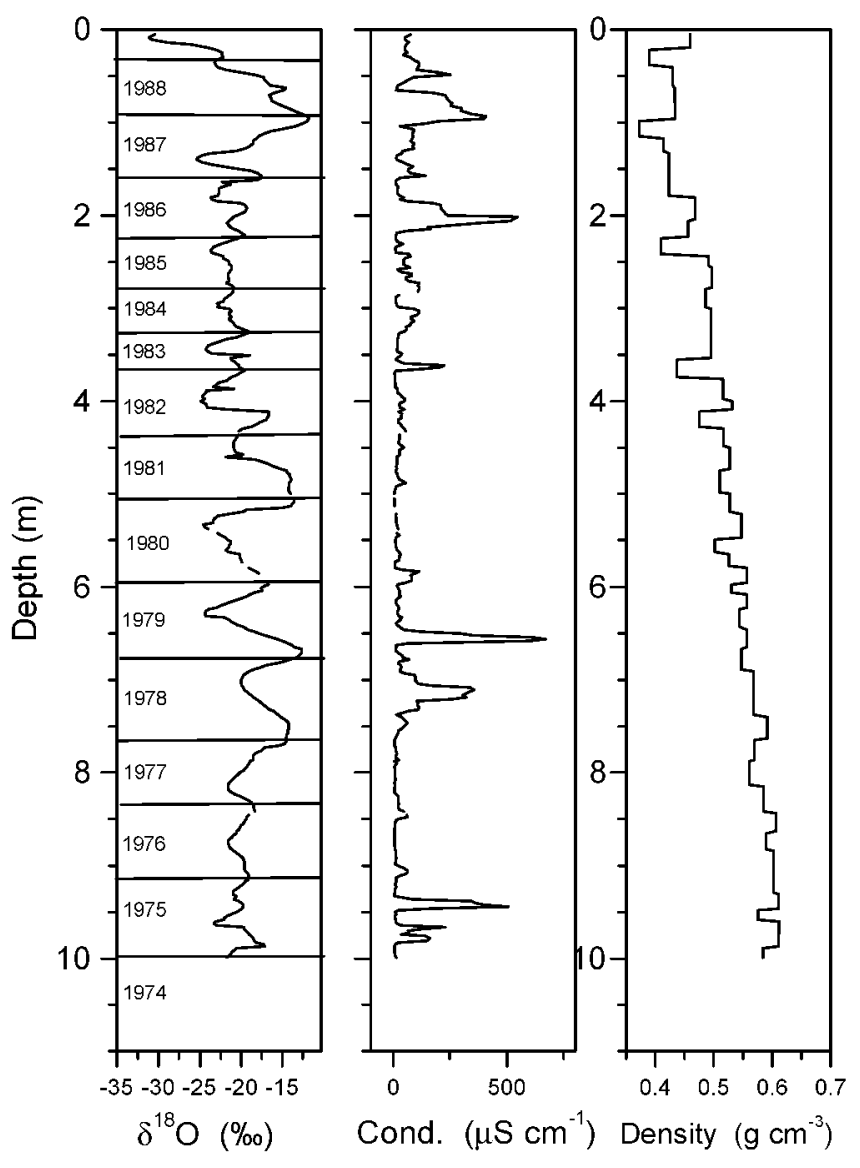

Fig. 3. $\delta^{18} \mathrm{O}$, electrolytical conductivity and density for FB0189 (Schlosser and others, 1999).

isotope stratigraphy, which differed from the ${ }^{3} \mathrm{H}$ dating by only 1 year. This yields a dating accuracy of about $5 \%$ (Oerter and others, 1997, 1999; Graf and others, 1999).

B04 covers the time period 1892-1981. The mean annual accumulation for this time period is $351 \mathrm{~kg} \mathrm{~m}^{-2} \mathrm{a}^{-1}$, with a standard deviation of the annual means of $91 \mathrm{~kg} \mathrm{~m}^{-2} \mathrm{a}^{-1}$.

Figure 3 shows $\delta^{18} \mathrm{O}$, electrolytical conductivity and density for FB0189. The $\delta^{18} \mathrm{O}$ profile does not show very regular seasonal variations, but the accumulation rates derived from it agree well with the accumulation measured at the stake array at GvN which is shown in Figure 4. The electrolytical conductivity does not show regular seasonal variations; the measured peaks are related to certain storm events.

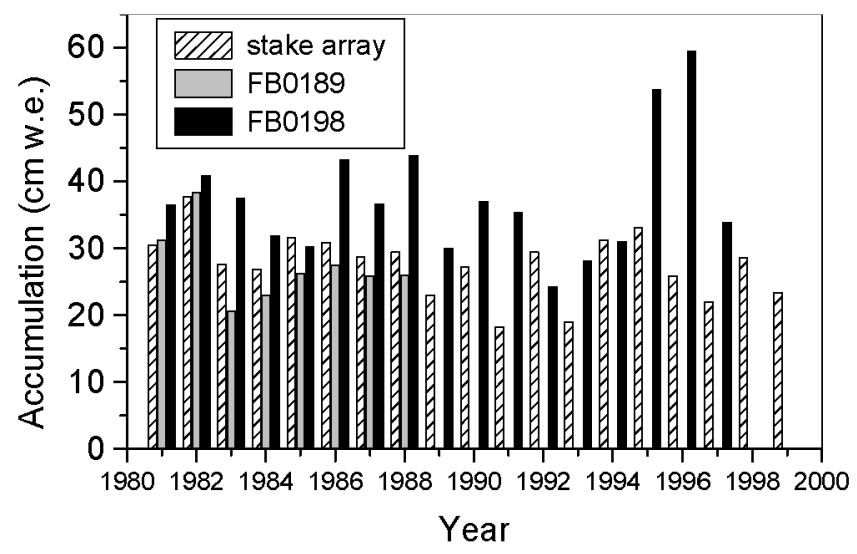

Fig. 4. Annual accumulation measured at stake array Neumayer (until 1991: GvN) and derived from FB0189, respectively. $\delta^{18} \mathrm{O}(\%)$

$\begin{array}{llllllllllllllll}-30 & -25 & -20 & -15 & -10 & -30 & -25 & -20 & -15 & -10 & -30 & -25 & -20 & -15 & -10\end{array}$

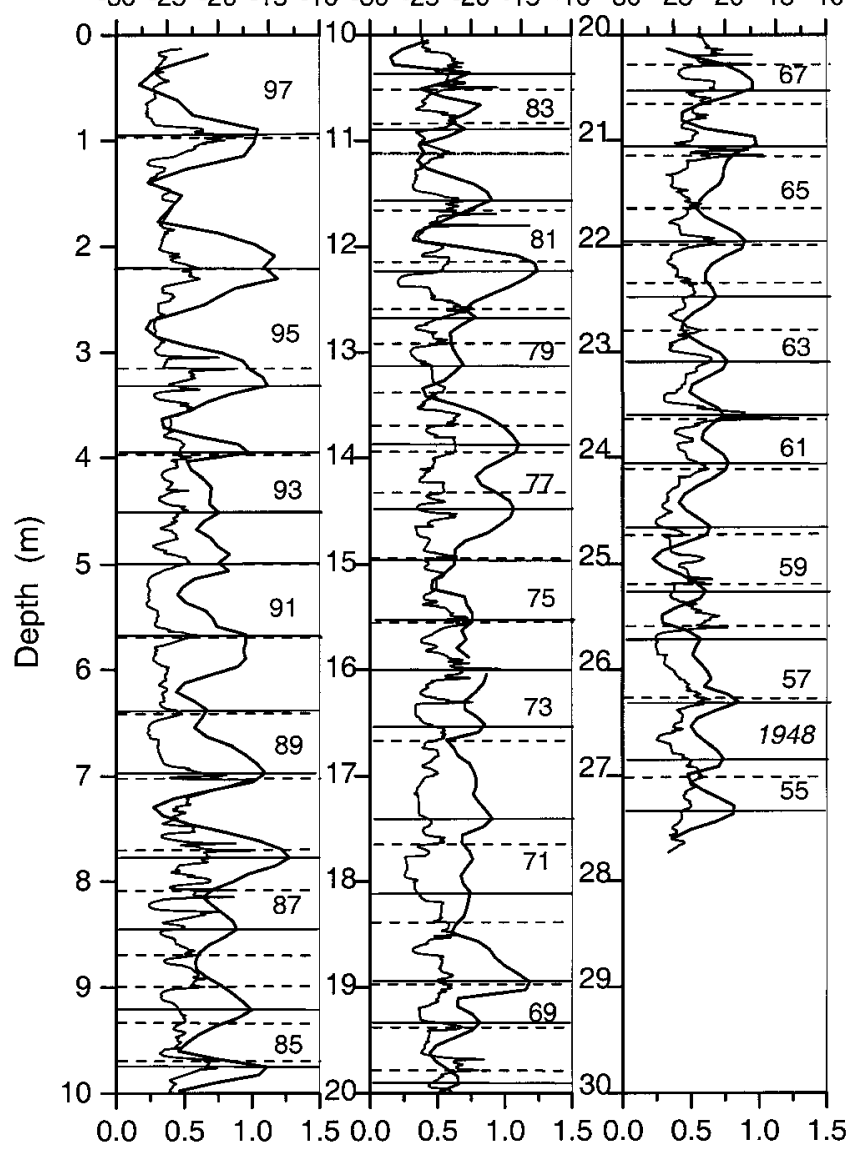

Electrical conductivity $\left(\mathrm{S} / \mathrm{m} \times 10^{5}\right)$

Fig. 5. Electrical conductivity (from DEP) (thin line) and $\delta^{18} \mathrm{O}$ (bold line) profiles of FB0198, with the corresponding dating (dashed and solid lines, respectively). Normal numbers correspond to the $\delta^{18} \mathrm{O}$ dating; 1948 (italic) is the first year of the DEP dating.

FB0198 was taken at the stake array " $15 \mathrm{~km}$ South". The core is $27.8 \mathrm{~m}$ long and covers the time period 1955-97. Figure 5 displays the profiles of electrical conductivity measured by means of DEP (Wilhelms and others, 1998) and of the ${ }^{18} \mathrm{O}$ content of this core.

\section{DATING OF THE CORES}

FB0198 was first dated using DEP measurements (Wilhelms and others, 1998). Dating by means of DEP profiles was also carried out on several cores from Amundsenisen by Oerter and others $(1999,2000)$. On the inland ice plateau, strong volcanic signals provided good time markers in addition to the seasonal signal. Unfortunately, a pronounced signal coinciding with the eruption of Mount Agung, Indonesia, in 1963 is missing in FB0198, which was drilled in the coastal region. Therefore layer counting within the DEP profile is more uncertain. Due to the high accumulation rate at this coastal site, the seasonal $\delta^{18} \mathrm{O}$ signal is well preserved.

Figure 5 shows the electrical conductivity and $\delta^{18} \mathrm{O}$ profiles for FB0198 together with the corresponding dating. For comparison, the DEP dating was first done independently of the $\delta^{18} \mathrm{O}$ dating. The numbers correspond to the $\delta^{18} \mathrm{O}$ dating; the first year of the DEP dating is 1948. The two dating methods yield different results. 


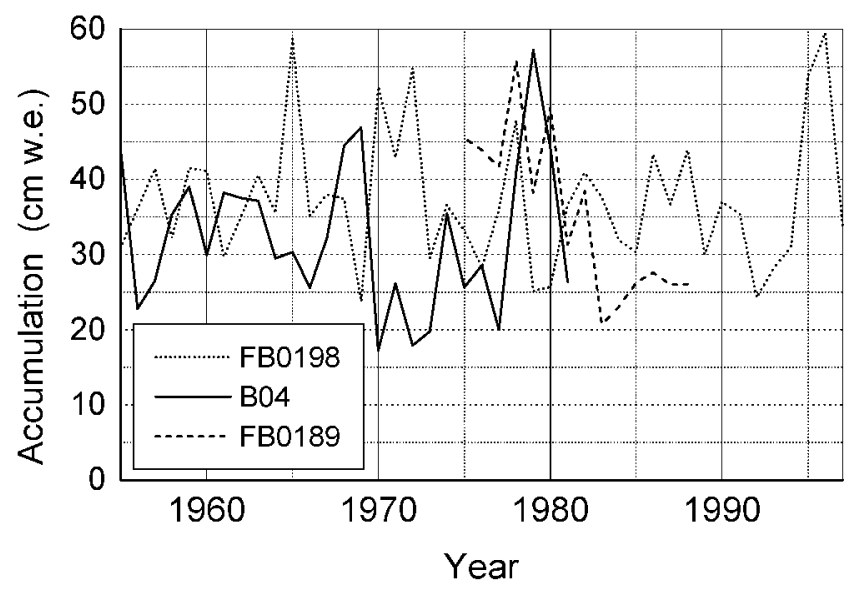

Fig. 6. Annual accumulation derived from B04, FB0189 and FB0198 for the time period 1955-97.

Differences are largest in those parts of the core in which the conductivity is fairly irregular, whereas the isotope profile shows clear seasonal variations. In these cases the $\delta^{18} \mathrm{O}$ signal is more reliable than the DEP signal, which can be disturbed by single precipitation events (like the electrolytical conductivity shown above for core FB0189). For the past two decades, we used the stake measurements to check this dating. Since the spatial variability of accumulation is high it is not possible to exactly prove the dating using the stake measurements, but the results support the assumption that for this core the seasonal variations of the $\delta^{18} \mathrm{O}$ provide a more exact dating tool than the DEP. There are still some uncertainties in the lower part of the core. Unfortunately, the stake measurements did not start until 1981.

The DEP dating is reliable when it can be checked using marked layers from well-known volcanic eruptions. Usually a combination of different dating methods yields a reliable result.

\section{AGGUMULATION RATES}

Figure 6 shows the accumulation rates derived from B04, FB0189 and FB0198 for the time period covered by all three cores, 1955-97. All three cores show high interannual variability of accumulation and do not agree well because of the high spatial variability of accumulation due to the extreme wind influence (Schlosser and others, 1999).

Figure $7 \mathrm{a}$ and $\mathrm{b}$ show the complete time series of accumulation for the two longer cores. Whereas in B04 a decreasing trend (significant at the 95\% level) can be found between 1892 and 1980 (Fig. 7a), FB0198 (Fig. 7b) shows no significant trend for the time period 1955-97. The time period covered by both cores, 1955-80, is too short for a statistically significant trend to be calculated.

The origin of the deeper layers of B04 lies about $15 \mathrm{~km}$ south of the drilling site. Therefore accumulation rates of B04 were corrected for the thinning of the annual layers due to the ice flow. Horizontal strain rates at the drilling site amount to $1.2 \times 10^{-3} \mathrm{a}^{-1}$ and $-0.5 \times 10^{-3} \mathrm{a}^{-1}$, respectively (IFAG, 1999). This yields a change in the annual-layer thickness of $0.07 \% \mathrm{a}^{-1}$. For the shorter core the thinning of the annual layers was negligible.

The trend in the corrected time series for B04 amounts to $1.05 \mathrm{~mm}$ w.e. $\mathrm{a}^{-1}$ (significant at the $95 \%$ level). However, the high spatial variability means that the data concerning trends must be interpreted with care.
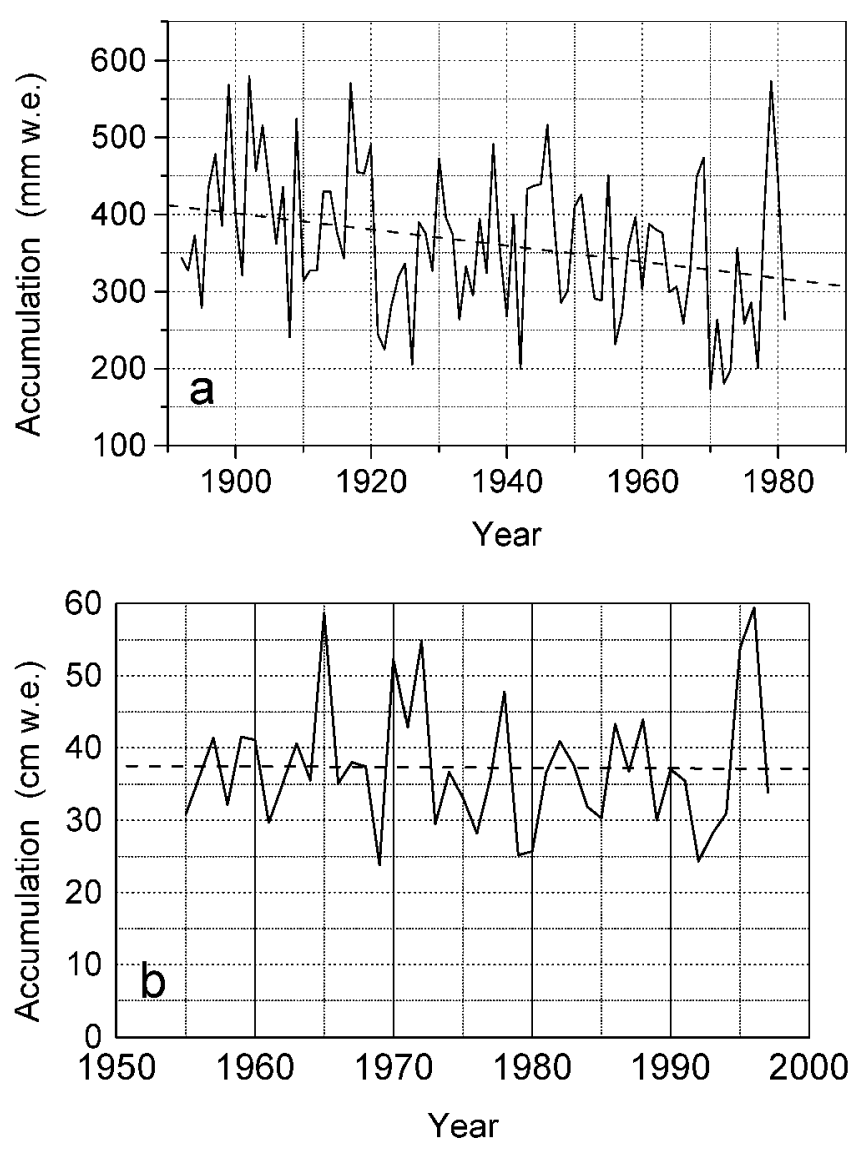

Fig. 7. (a) Annual accumulation derived from B04 for the time period 1892-1981. (b) Annual accumulation derived from FB0198 for the time period 1955-97.

The mean accumulation rate for $1892-1980$ (B04) is $362 \mathrm{~kg} \mathrm{~m}^{-2} \mathrm{a}^{-1} \quad\left(\sigma=95 \mathrm{~kg} \mathrm{~m}^{-2} \mathrm{a}^{-1}\right)$, and for 1955-97 (FB0198) is $374 \mathrm{~kg} \mathrm{~m}^{-2} \mathrm{a}^{-1}\left(\sigma=87 \mathrm{~kg} \mathrm{~m}^{-2} \mathrm{a}^{-1}\right)$.

\section{ISOTOPE RATIOS}

Figure 8 shows the mean annual $\delta^{18} \mathrm{O}$ for B04, FB0189 and FB0198 for the time period since 1955. The isotope values of the three cores agree much better than the accumulation rates. This was also found on Amundsenisen (Graf and others, 2002). We assume that this is because the isotope ratios are relatively uniform during single precipitation events, whereas accumulation is dependent on topography

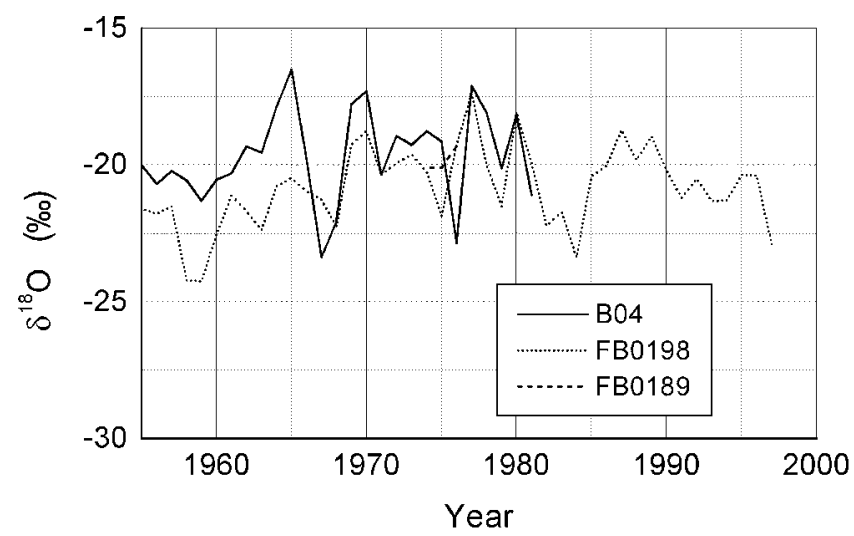

Fig. 8. Annual mean $\delta^{18} \mathrm{O}$ for B04, FB0189 and FB0198 for the time period 1955-97. 


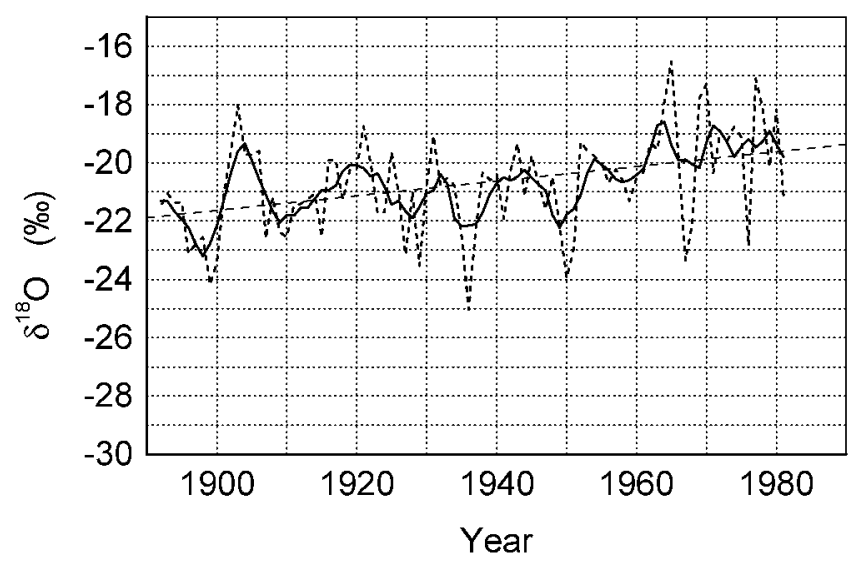

Fig. 9. Annual mean $\delta^{18}$ O for B04 for the time period 1892-1981 (thin line: annual values; bold line: 5 year running mean).

and can be altered even by extremely slight depressions or rises of the surface.

Figure 9 shows the mean annual $\delta^{18} \mathrm{O}$ for $\mathrm{B} 04$ for the time period 1892-1981. B04 shows an increasing trend between 1892 and 1980 (significant at the 95\% level). FB0198 also shows increasing $\delta^{18} \mathrm{O}$ values during this century until the 1980s; later it shows slightly decreasing values. For the time period since 1981, for which temperature measurements are available, no significant correlation is found between mean annual temperature and $\delta^{18} \mathrm{O}$ from FB0198, because at Ekströmisen the annual mean $\delta^{18} \mathrm{O}$ is strongly dependent on seasonal distribution of accumulation (Schlosser, 1999). The interannual variability of seasonality leads to a bias in the core, which makes it impossible to derive mean annual temperatures from mean annual $\delta^{18} \mathrm{O}$. For smaller time-scales, which can be investigated using samples of freshly fallen snow, the $\delta^{18} \mathrm{O}$ at Neumayer is highly correlated to temperature. Pfaff (1993) found a good correlation of monthly means of air temperature and $\delta^{18} \mathrm{O}$ values of surface snow samples taken between 1981 and 1990. The best correlation between $\delta^{18} \mathrm{O}$ and temperature was found at the lifting condensation level $(r=0.93$, significant at the $95 \%$ confidence level).

Figure 10 shows the annual mean temperature for the time period 1981-99 at GvN (until 1991) and Neumayer (since 1992). The annual mean air temperature at Neumayer/GvN is $-15.8^{\circ} \mathrm{C}$. Only small deviations from the mean are observed. Except for 1996, which was an exceptionally warm year, the

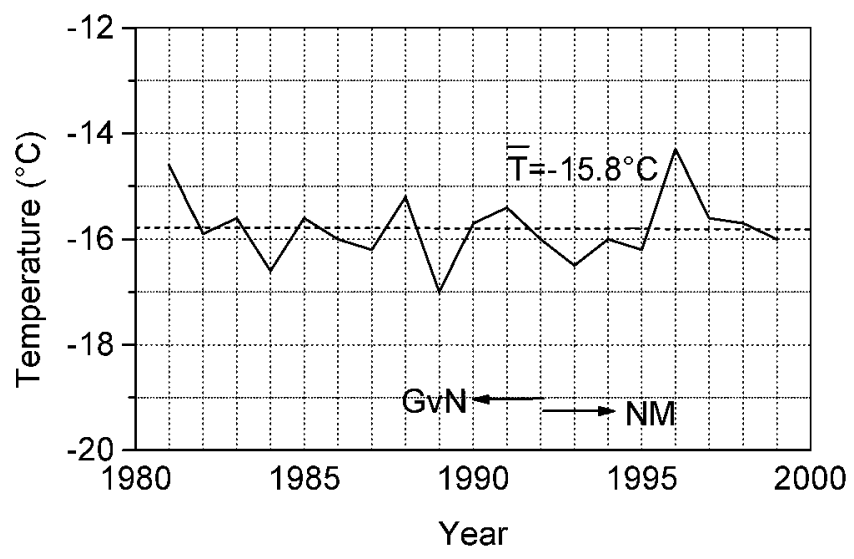

Fig. 10. Annual mean air temperature 1981-99, measured at

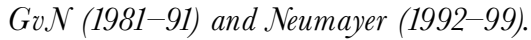

mean annual temperatures differ $<1{ }^{\circ} \mathrm{C}$ from the average. No variations corresponding to the large variations of $\delta^{18} \mathrm{O}$ in FB0198 since 1981 can be found in the temperature curve.

\section{DISGUSSION}

Different authors have studied changes in accumulation rates in various parts of Antarctica. An increase in accumulation during the second half of the 20th century was found at South Pole by Mosley-Thompson and others (1995). Morgan and others (1991) also found increasing accumulation values between 1960 and 1990. Peel (1992) reports increasing accumulation for the peninsula region, too. Recent studies at the Ronne Ice Shelf and Amundsenisen have not shown the same trends. Oerter and others (2000) investigated five cores at Amundsenisen, which covered the time period from the beginning of the 19th century. The stacked series of these cores showed an increasing trend in accumulation rates for the 20 th century (6.3-7.4 $\mathrm{kg} \mathrm{m}^{-2} \mathrm{a}^{-1}$ since 1905). Isaksson and others (1996, 1999) found no significant trends in accumulation rates in Dronning Maud Land. Graf and others (1999) obtained the same result for the second half of the 20th century on Foundation Ice Stream, Ronne Ice Shelf. No significant trend in accumulation rates was found there. Obviously there is no uniform trend over Antarctica.

Isaksson and others (1999) correlated accumulation rates from Fimbulisen to annual mean temperatures from the third South African National Antarctic Expedition (SANAE III), which was situated close to the coast of Fimbulisen. The yearto-year correlation is not significant, but the multi-year trends are similar. The accumulation rates from Neumayer show a different behaviour. Although SANAE III is situated only $200 \mathrm{~km}$ east of Neumayer and is influenced by the same synoptic systems, usually with a time lag of only a few hours, the annual mean air temperatures of Neumayer and SANAE III, respectively, are not well correlated, and the SANAE III temperature shows much higher variations than the annual temperature at Neumayer.

At Amundsenisen, Oerter and others (2000) found an increasing trend in $\delta^{18} \mathrm{O}$ for the 20th century in the stacked time series mentioned above.

At Neumayer, the stable-isotope ratios show an increasing trend until 1980. For the next two decades, the $\delta^{18} \mathrm{O}$ shows large variations, with decreasing values towards the end of the 20th century. FB0198 is too short to calculate a statistically significant trend. However, the observed variations in $\delta^{18} \mathrm{O}$ cannot be explained using the temperature data. Factors other than temperature, such as changes in atmospheric circulation, must be involved.

Reliable interpretation of ice cores requires a better understanding of the precipitation conditions and of the general atmospheric circulation at present and for former climates.

\section{GONGLUSIONS}

Accumulation rates around Neumayer are about $360 \mathrm{~kg} \mathrm{~m}^{-2}$ $\mathrm{a}^{-1}$. The spatial distribution of accumulation is very uneven due to large wind influence. No trend was found in accumulation rates during the last 50 years. Earlier in the century, the accumulation decreased. Trends have to be interpreted very cautiously because of the high interannual variability of accumulation. In spite of the highly irregular spatial accumulation distribution, the stable-isotope ratios show 
little spatial variability, presumably because the isotope ratios are the same over a wider area during one precipitation event. $\delta^{18} \mathrm{O}$ values increased during the 20 th century until 1980; since the late 1980s a decrease is observed. The $\delta^{18} \mathrm{O}$ variations during the last two decades of the 20th century are not directly related to temperature, since the mean annual temperature at Neumayer was nearly constant during this time period.

\section{AGKNOWLEDGEMENTS}

We would like to thank all of our colleagues who carried out fieldwork at Neumayer and analysis of the cores. This study has received financial support from the Austrian Science Fund (grant No. P13429-GEO). Analysis of B04 was carried out at the National Research Centre for Environment and Health (GSF), Neuherberg, Germany; thanks are due to W. Graf.

\section{REFERENGES}

Bentley, C. R. and M. B. Giovinetto. 1991. Mass balance of Antarctica and sea level change. In Weller, G., C. L. Wilson and B. A. B. Severin, eds. International Conference on the Role of the Polar Regions in Global Change: proceedings of a conference held June 11-15, 1990 at the University of Alaska Fairbanks. Vol. II. Fairbanks, AK, University of Alaska. Geophysical Institute/Center for Global Change and Arctic System Research, 481-488.

Giovinetto, M. B. and C. R. Bentley. 1985. Surface balance in ice drainage systems of Antarctica. Antarct. F. U.S., $20(4), 6-13$.

Giovinetto, M. B. and H. J. Zwally. 2000. Spatial distribution of net surface accumulation on the Antarctic ice sheet. Ann. Glaciol., 31, 171-178.

Giovinetto, M. B., N. M. Waters and C. R. Bentley. 1990. Dependence of Antarctic surface mass balance on temperature, elevation, and distance to open ocean. F. Geophys. Res., 95(D4), 3517-3531.

Graf, W., O. Reinwarth, H. Oerter, C. Mayer and A. Lambrecht. 1999. Surface accumulation on Foundation Ice Stream, Antarctica. Ann. Glaciol., 29, 23-28.

Graf, W. and 6 others. 2002. Stable-isotope records from Dronning Maud Land, Antarctica. Ann. Glaciol., 35 (see paper in this volume).

Institut für Angewandte Geodäsie (IfAG). 1999. Ekströmisen (SR29-30/SW), Antarktis. Maps of ice shelf kinematics. Frankfurt am Main, Institut für Angewandte Geodäsie. (Topographische Karte und Satellitenbildkarte, scale 1:500 000).

Isaksson, E., W. Karlén, N. Gundestrup, P. Mayewski, S. Whitlow and M. Twickler. 1996. A century of accumulation and temperature changes in Dronning Maud Land, Antarctica. 7. Geophys. Res., 101(D3), 7085-7094.

Isaksson, E., M. R. van den Broeke, J.-G. Winther, L. Karlöf, J. F. Pinglot and N. Gundestrup. 1999. Accumulation and proxy-temperature variability in Dronning Maud Land, Antarctica, determined from shallow firn cores. Ann. Glaciol., 29, 17-22.

Morgan, V. I., I. D. Goodwin, D. M. Etheridge and C.W. Wookey. 1991. Evidence from Antarctic ice cores for recent increases in snow accumulation. Nature, 354(6348), 58-60.

Mosley-Thompson, E. and 6others. 1995. Recent increase in South Pole snow accumulation. Ann. Glaciol., 21, 131-138.

Oerter, H., W. Graf and E. Schlosser. 1997. Stable isotope contents of near surface firn from Neumayer base towards Dronning Maud Land, Antarctica. In Oerter, H., comp. Filchner-Ronne Ice Shelf Programme (FRISP). Report No. 11 (1997). Bremerhaven, Alfred Wegener Institute for Polar and Marine Research, 56-64.

Oerter, H., W. Graf, F. Wilhelms, A. Minikin and H. Miller. 1999. Accumulation studies on Amundsenisen, Dronning Maud Land, by means of tritium, dielectric profiling and stable-isotope measurements: first results from the 1995-96 and 1996-97 field seasons. Ann. Glaciol., 29,1-9.

Oerter, H. and 6 others. 2000. Accumulation rates in Dronning Maud Land, Antarctica, as revealed by dielectric-profiling measurements of shallow firn cores. Ann. Glaciol., 30, 27-34.

Peel, D. A. 1992. Ice core evidence from the Antarctic Peninsula region. In Bradley, R. S. and P. D. Jones, eds. Climate since A.D. 1500. London and New York, Routledge, 549-571.

Pfaff, C. 1993. ${ }^{2} \mathrm{H}-$ und ${ }^{18} \mathrm{O}-$ Gehalte in den Niederschlägen in Abhängigkeit von der meteorologischen Situation im Bereich der Georg-vonNeumayer-Station, Antarktis. (Ph.D. thesis, University of Innsbruck.)

Reinwarth, O., W. Rauert, W. Stichler and H. Moser. 1982. Preliminary investigations on accumulation at the Filchner/Ronne ice shelves and Atka Bay. Ann. Glaciol., 3, 274-278.

Reinwarth, O., W. Graf, W. Stichler, H. Moser and H. Oerter. 1985. Investigations of the oxygen-18 content of samples from snow pits and ice cores from the Filchner-Ronne ice shelves and Ekström ice shelf. Ann. Glaciol., 7, 49-53.

Schlosser, E. 1999. Effects of seasonal variability of accumulation on yearly mean $\delta^{18} \mathrm{O}$ values in Antarctic snow. F. Glaciol., 45(151), 463-468.

Schlosser, E., H. Oerter andW. Graf. 1999. Surface mass balance investigations on Ekströmisen, Antarctica, 1980-1996. Ber. Polarforsch./Rep. Pol. Res. 313

Schytt, V. 1958a. Glaciology II(A). Snow studies at Maudheim. NorwegianBritish-Swedish Antarctic Expedition, 1949-52. Sci. Results IV.

Schytt, V. 1958b. Glaciology II(B). Snow studies inland. Norwegian-BritishSwedish Antarctic Expedition, 1949-52. Sci. Results IV.

Swithinbank, C. 1957a. Glaciology I (A). The morphology of the ice shelves of western Dronning Maud Land. Norwegian-British-Swedish Antarctic Expedition, 1949-52. Sci. Results III.

Swithinbank, C. 1957b. Glaciology I(B). The regime of the ice shelf at Maudheim as shown by stake measurements. Norwegian-British-Swedish Antarctic Expedition, 1949-52. Sci. Results III.

Van Lipzig, N. P. M. 1999. The surface mass balance of the Antarctic ice sheet: a study with a regional atmospheric model. (Ph.D. thesis, Utrecht University.)

Wilhelms, F., J. Kipfstuhl, H. Miller, K. Heinloth and J. Firestone. 1998. Precise dielectric profiling of ice cores: a new device with improved guarding and its theory. f. Glaciol., 44(146), 171-174. 